sp 13

\begin{tabular}{|c|c|}
\hline $\begin{array}{l}\text { 2. To: (Receiving Organization) } \\
\text { DISTR(BUT/ON }\end{array}$ & $\begin{array}{l}\text { 3. From: (originating Organization) } \\
\text { Analytical Services }\end{array}$ \\
\hline $\begin{array}{l}\text { 5. Proj./Prog-/Dept./Div.: } \\
\text { 222-S/AS/TWRS }\end{array}$ & $\begin{array}{l}\text { 6. Design Authority/ Design Agent/Cog. } \\
\text { Engr.: } \\
\text { K. Wehner }\end{array}$ \\
\hline
\end{tabular}

\section{Originator Remarks:}

KEYWORDS: Test Plan, Evaporator Sample Preparation.

Evaporator Waste Processing
11. Receiver Remarks:
11A. Design Baseline Document?
[] Yes
$[x]$ No

\section{Related EDT No.: \\ none \\ 7. Purchase Order No.: \\ none}

9. Equip./Component No.: none

10. System/Bldg./Facility: none

12. Major Assm. Dwg. No.: none

13. Permit/Permit Application No.: none

14. Required Response Date:

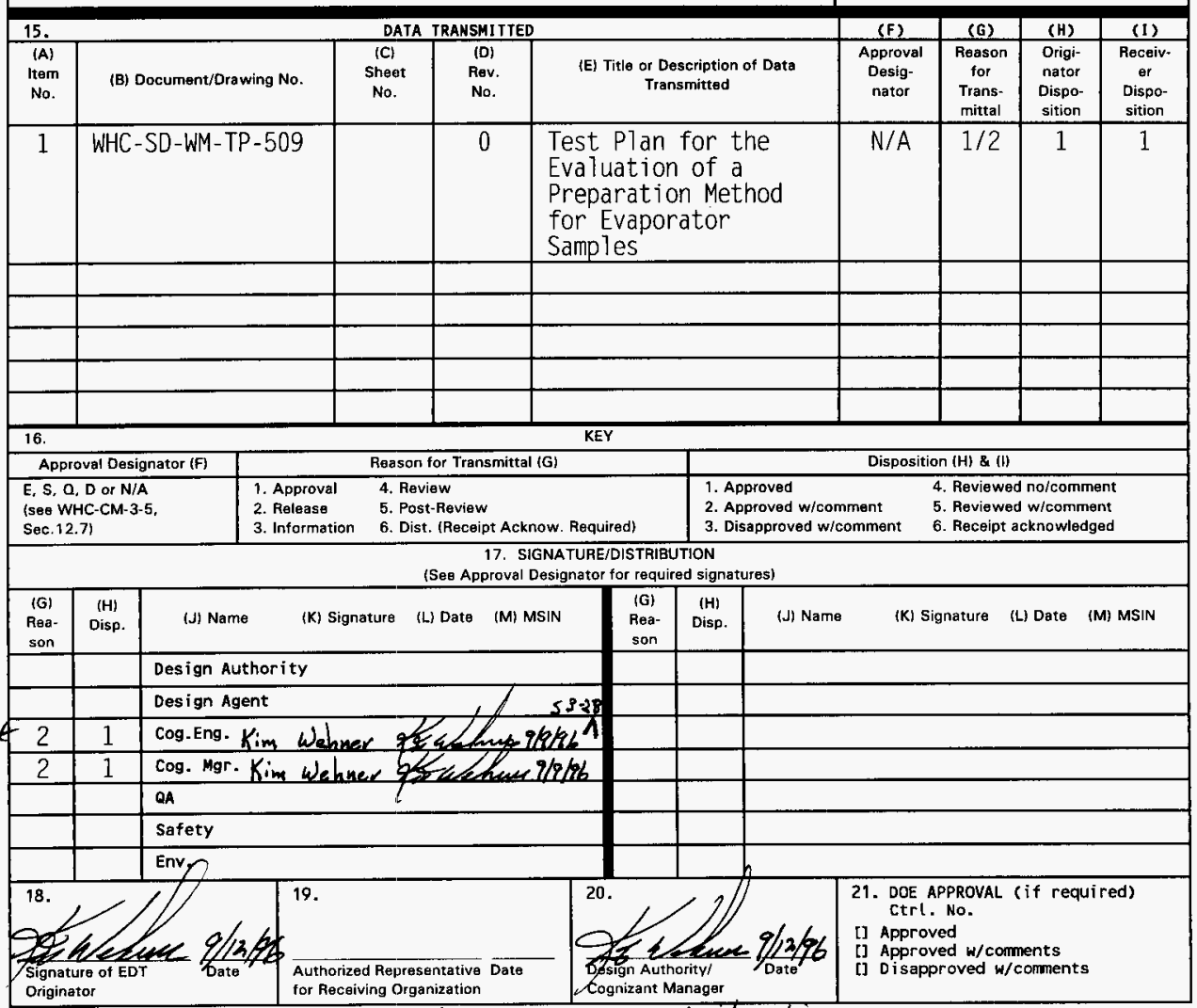




\title{
Test Plan For The Evaluation Of A Preparation Method For Evaporator Samples
}

\author{
Kim Wehner
}

Westinghouse Hanford Company, Richland, WA 99352

U.S. Department of Energy Contract DE-AC06-87RL10930

$\begin{array}{ll}\text { EDT/ECN: } 612186 & \text { UC: } 601 \\ \text { Org Code: } 75744 & \text { Charge Code: } N 1799 \\ \text { B\&R Code: EW3120071 } & \text { Total Pages: } 284 / \mathrm{km} / \mathrm{m}\end{array}$

Key Words: Test Plan. Evaporator Sample Preparation. Evaporator Waste Processing

Abstract: This "Test Plan" will be used to evaluate the use of existing laboratory equipment for the determination of the organic material carried over from the feed to the condensate during evaporator waste processing. It will use existing procedures to simulate the distillation of organic compounds during the evaporator operation and to determine the organic compounds carried over and their concentrations. Although the amounts of organics in the synthetic waste may not reflect any particular waste tank, the goal is to track the pathway of the various organics.

TRADEMARK DISCLAIMER. Reference herein to any specific commercial product, process, or service by trade name, trademark, manufacturer, or otherwise, does not necessarily constitute or imply its endorsement, recommendation, or favoring by the United States Government or any agency thereof or its contractors or subcontractors.

Printed in the United States of America. To obtain copies of this document, contact: WHC/BCS Document Control Services, P.O. Box 1970, Mailstop H6-08, Richland HA 99352, Phone (509) 372-2420; Fax (509) 376-4989.
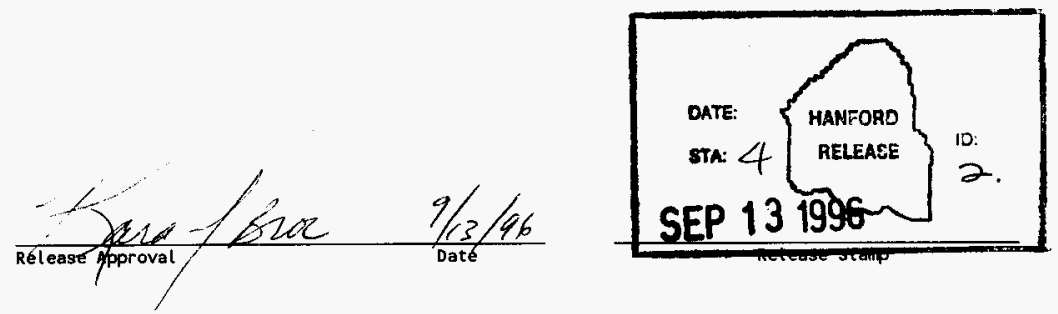

Approved for Public Release 


\section{Test Plan For The Evaluation Of A Preparation Method For Evaporator Samples}

A method is needed to approximate the amount of organic compounds in candidate feed tank that would be carried over during evaporator waste processing.

\section{$1.0 \quad$ INTRODUCTION}

This "Test Plan" will be used to evaluate the use of existing laboratory equipment for the determination of the organic material carried over from the feed to the condensate during evaporator waste processing. It will use existing procedures to simulate the distillation of organic compounds during the evaporator operation and to determine the organic compounds carry over and their concentrations. Although the amounts of organics in the synthetic waste may not reflect any particular waste tank, the goal is to track the pathway of the various organics.

\section{$2.0 \quad$ RESPONSIBILITIES}

2.1 Analysis - The 222-S Standards Laboratory will prepare the "Synthetic Waste" and 222-S Organic Chemistry will spike the "Synthetic Waste" and perform analysis of the boildown samples.

2.2 The cognizant scientist will be responsible for modifications to the test plan that may be required.

2.3 Data Review and Results - Upon completion of the analysis a report will be written which will include data and a narrative.

\subsection{DESCRIPTION OF TESTING}

3.1 A portion of the "Synthetic Waste" (see Table 1) will be spiked with "Target Compounds" (see Table 2). Approximately $100 \mathrm{ml}$ of the spiked solution will be needed for each boildown. The unspiked portion will be left to serve as a blank.

3.2 Boildowns (LT-519-183) will be performed at a pressure of 60 torr and completed when the temperature reaches $135 \mathrm{deg} F$ or at a waste volume reduction of $80 \%$, which ever comes first. 
3.3 The spiked stock solution, boildown condensate, and bottoms will be analyzed for VOA and SVOA using LA-523-131, LA-523-437, LA-523-405, LA-523-132, and LA-523-406. Samples will be refrigerated until analysis or extraction is performed.

3.4 Two $1 \mathrm{ml}$ samples of stock solution, condensate, and bottoms will be taken and submitted for TIC and TC analysis.

TABLE 1. Synthetic Waste Composition

\begin{tabular}{|l|c|c|}
\hline & $\mathrm{g} / \mathrm{l}$ & Molar \\
\hline $\mathrm{NaOH}$ & 22.8 & 0.569 \\
\hline $\mathrm{NaA1O} 2$ & 5.3 & 0.064 \\
\hline $\mathrm{NaNO} 3$ & 64.8 & 0.762 \\
\hline $\mathrm{NaNO} 2$ & 22.9 & 0.332 \\
\hline $\mathrm{Na2CO3}$ & 29.1 & 0.274 \\
\hline $\mathrm{Na3PO} 4$ & 1.6 & 0.0095 \\
\hline $\mathrm{Na} 2 \mathrm{SO} 4$ & 4.8 & 0.0337 \\
\hline $\mathrm{NaF}$ & 6.6 & 0.158 \\
\hline
\end{tabular}

Specific gravity of approximately 1.1 
WHC-SD-WM-TP-509, Rev. 0

Table 2. Spiking Concentrations

\begin{tabular}{|l|c|}
\hline \multicolumn{1}{|c|}{ Feed Constituent } & Spike Level $(\mathrm{mg} / \mathrm{L})$ \\
\hline Acetone & 25 \\
\hline 1-Butanol & 2500 \\
\hline 2-Butoxyethanol & 50 \\
\hline 2-Butanone & 25 \\
\hline Tri-Butyl Phosphate & 200 \\
\hline 2-Hexanone & 25 \\
\hline 2-Pentanone & 25 \\
\hline Methyl Isobutyl Ketone & 25 \\
\hline Tetrahydrofuran & 50 \\
\hline
\end{tabular}

\section{0 PROCEDURES}

4.1 Appropriate QC will be determined by the cognizant scientist.

4.2 LA-523-131, LA-523-132, LA-523-406, LA-523-405, LA-523-437, and LA-519183

5.0 SAFETY

5.1 Observe general organic laboratory safety rules

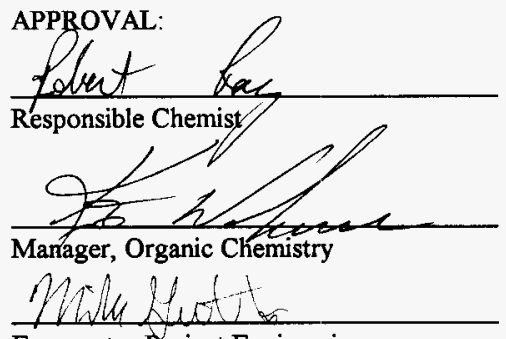

Evaporator Project Engineering
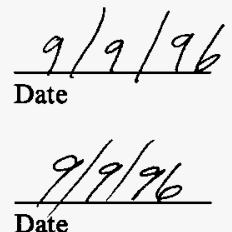

$9 / 4 / 96$

Date 